\title{
Effect Of Value Of Resistance Announcement To Thd In Electrical System Faculty Of Engineering University Udayana Denpasar
}

\author{
I G N Janardana ${ }^{1}$, I WArta Wijaya ${ }^{2}$, I N Karnata Mataram ${ }^{3}$ \\ 1,2Electrical Engineering Department, Faculty of Engineering, \\ Udayana University, Bukit Jimbaran, Indonesian \\ 1janardana@unud.ac.id \\ ${ }^{3}$ Civil Engineering Department, Faculty of Engineering, \\ Udayana University, Bukit Jimbaran, Indonesian
}

\begin{abstract}
AC (Air Conditioner), TV, lamp, LCD and others are categorized as nonlinear load generating harmonics. The high content of harmonics has a negative impact on the quality of electrical power. The result of measurement of THD (Total Harmonic Distortion) current at $9 \mathrm{ohm}$ ground resistance value at phase $\mathrm{R}=$ $9,8 \%$, phase $\mathrm{S}=11,0 \%$, phase $\mathrm{T}=7,5 \%$ exceed from standard value IEEE 519 Year 2014 equal to $\leq 5,0 \%$, THD measurement of phase voltage $\mathrm{R}=1.4 \%$, phase $\mathrm{S}=1.2 \%$, phase $\mathrm{T}=1.3 \%$, meet the maximum $\mathrm{THDv}$ standard of $\leq 5 \%$. To overcome this problem, it was observed the effect of the value of ground resistance to THDi and THDv on the electrical system of the College of Engineering Faculty of Denpasar. This method of analysis with ETAP software simulation.

With grounding system $\leq 3 \mathrm{ohm}$ only effect on current THD only with decreasing value of THDi become: phasa $\mathrm{R}=4,2 \%$, phase $\mathrm{S}=5 \%$ and phase $\mathrm{T}=4,3 \%$, meaning with grounding system $\leq 3 \mathrm{ohm}$ THD current fulfill IEEE 519 - 2014 standard <5\%. while THD voltage has no effect (THD value of fixed voltage). Several studies have suggested that THD repair can be done by filter installation. However in this study the installation of grounding system $\leq 3 \mathrm{ohms}$ can reduce the value of current THD.
\end{abstract}

\section{Index Terms - Grounding System, Harmonics, Power Quality}

\section{INTRODUCTION}

Lights, Air Conditioner, TV, LCD and others are non linear load type, current wave and output voltage are not proportional to the waveforms, causing distortion in current and voltage waves known as harmonics. The harmonics content in the customer has a negative impact on the quality of electric power and can damage the equipment due to the rise in temperature on the cable and electrical panel connectors.

The result of THDi measurement at peak load in electrical system of Faculty of Engineering Denpasar at 9 ohm ground resistance, phase $\mathrm{R}=9,8 \%$, phase $\mathrm{S}=11,0 \%$, phase $\mathrm{T}=$ 7,5\%, exceeds standard value IEEE 519 Year 2014 $\leq 5.0 \%$, THD (Total Harmonic Distortion) voltage of phase $\mathrm{R}=1.4 \%$, phase $\mathrm{S}=1.2 \%$, phase $\mathrm{T}=$ $1.3 \%$, the condition meets the maximum THDv standard of $\leq 5 \%$. will continuously lead to decreased power quality and result in damage to equipment on the electrical panel.

Based on the problem is done research of the influence of the value of grounding resistance to THD current and THD voltage on the electrical system. to maintain the quality of electrical power.

\section{REVIEW OF LITERATURES}

\subsection{State of The Art}

1. Non-linear loads contribute greatly to the increase in THD, the result of analysis of THDi percentage of $34.80 \%$ and $25.67 \%$, when nonlinear loads are fully operational [1]. 
2. Soil at Faculty of Engineering Udayana University Denpasar measured soil resistance value $=30.14 \mathrm{ohm}-\mathrm{m}$, depth of electrode installation at least 13 meters to get ground resistance value $<3 \mathrm{Ohm}$ [2].

3. The research of Janardana (2016) in Faculty of Engineering of Udayana University of Denpasar obtained the characteristics of each grounding system such as $1 \operatorname{rod}, 2 \operatorname{rod} \mathrm{s}<\mathrm{L}, 2 \operatorname{rod} \mathrm{s}>\mathrm{L}$, plates and grids to obtain the ground resistance $<3 \mathrm{ohm}[3]$.

\subsection{Grounding System}

The grounding system is installed to drain the lightning current to the ground, so that the system and humans around it avoid the lightning strikes. The four parts of the electrical installation that must be earthed are [4], [5], [6]:

a) The installation parts are made of metal and can easily be touched humans.

b) Electric discharge section lightning arrester.

c) Lightning wire at the top of the transmission line.

d) The neutral point of the transformer or the neutral point of the generator.

\subsection{Harmonization}

Harmonics arise due to the operation of non-linear electrical loads. The high harmonics result in poor power quality [7], [8], [9].

Two harmonic criteria are current harmonic distortion (THDi) and harmonic strain (THDv).

TABLE I

HARMONIC CURRENT DISTORTION LIMIT WITH A VOLTAGE RATING OF 120V TO 69KV [10]

\begin{tabular}{|c|c|c|c|c|c|c|}
\hline \multicolumn{7}{|c|}{ Maximum harmonic current distortion in percent } \\
of $\mathrm{I}_{\mathrm{L}}$ \\
\hline \multicolumn{7}{|c|}{ Individual harmonic ordee (odd harmonic) } \\
\hline $\begin{array}{c}\mathrm{I}_{\mathrm{SC}} / \mathrm{I} \\
\mathrm{L}\end{array}$ & $3 \leq \mathrm{h} \leq$ \\
11 & $\begin{array}{c}11 \leq \mathrm{h} \\
\leq 17\end{array}$ & $\begin{array}{c}17 \leq \mathrm{h} \\
\leq 23\end{array}$ & $\begin{array}{c}23 \leq \\
\mathrm{h} \\
\leq 35\end{array}$ & $\begin{array}{c}35 \leq \\
\mathrm{h} \leq 5 \\
0\end{array}$ & $\begin{array}{c}\mathrm{TH} \\
\mathrm{D}\end{array}$ \\
\hline$<20$ & 4.0 & 2.0 & 1.5 & 0.6 & 0.3 & 5.0 \\
\hline $\begin{array}{c}20< \\
50\end{array}$ & 7.0 & 3.5 & 2.5 & 1.0 & 0.5 & 8.0 \\
\hline $\begin{array}{c}50 \\
<10 \\
0\end{array}$ & 10.0 & 4.5 & 4.0 & 1.5 & 0.7 & $\begin{array}{c}12 . \\
0\end{array}$ \\
\hline $\begin{array}{c}100 \\
<10 \\
00\end{array}$ & 12.0 & 5.5 & 5.0 & 2.0 & 1.0 & $\begin{array}{c}15 . \\
0\end{array}$ \\
\hline $\begin{array}{c}>10 \\
00\end{array}$ & 15.0 & 7.0 & 6.0 & 2.5 & 1.4 & $\begin{array}{c}20 . \\
0\end{array}$ \\
\hline
\end{tabular}

THDi harmonics even sequence is limited to $25 \%$ of the odd-order harmonics above.
Maximum harmonic current distortion in percent of $I_{L}$

The current distortion caused by a dc wave rectifier $\mathrm{dc}$ is not permitted or not included in the table above.

with :

$\mathrm{I}_{\mathrm{sc}}=$ Max short circuit current $\mathrm{di}$ PCC (Point of Common Coupling)

$\mathrm{I}_{\mathrm{L}}=$ Max load current (fundamental load flow) di PCC

With :

$\mathrm{I}_{\mathrm{sc}}=$ Max short circuit current in PCC (Point of Common Coupling).

$\mathrm{I}_{\mathrm{L}}=$ Max load current (fundamental load flow) in PCC.

According to IEEE Standard 519-2014, to know the maximum THDi limit on the utility, we must know the short-circuit ratio. $\mathrm{SC}_{\text {ratio }}$ is searched by the formula:

$\mathrm{SC}_{\text {ratio }}=\frac{I_{S C}}{I_{L}}$

Where, Isc (short circuit current) is searched by the

formula: $\mathrm{Isc}=\frac{\mathrm{KVA} \times 100}{\sqrt{3} \times \mathrm{KV} \times \mathrm{Z}(\%)}$

IL (maximum load current) is searched by the formula:

$$
\mathrm{I}_{\mathrm{L}}=\frac{K W}{P F \cdot \sqrt{3} \cdot K V}
$$

$\mathrm{I}_{\mathrm{SC}}=$ Maximum short circuit current on PCC.

$I_{L}=$ Maximum load current

$\mathrm{KW}=$ Total power active

TABLE II

VOLTAGE DISTORTION LIMIT [10]

\begin{tabular}{|c|c|c|}
\hline $\begin{array}{c}\text { BusVoltage at } \\
\text { PCC }\end{array}$ & $\begin{array}{c}\text { Individual } \\
\text { Voltage } \\
\text { Distortion } \\
(\%)\end{array}$ & $\begin{array}{c}\text { Total harmonic } \\
\text { distortion } \\
\text { THD }(\%)\end{array}$ \\
\hline $\mathrm{V} \leq 1.0 \mathrm{kV}$ & 5.0 & 8.0 \\
\hline $\begin{array}{c}1 \mathrm{kV}<\mathrm{V}<69 \\
\mathrm{kV}\end{array}$ & 3.0 & 5.0 \\
\hline $\begin{array}{c}69 \mathrm{kV}<\mathrm{V} \leq \\
161 \mathrm{kV}\end{array}$ & 1.5 & 2.5 \\
\hline $161 \mathrm{kV}<\mathrm{V}$ & 1.0 & 1.5 \\
\hline
\end{tabular}

\subsection{Non-Linear Load}

Nonlinear loads result in harmonics that have impedances that are not constant every period of inputs [11]. 


\section{RESEARCH METHODS}

\subsection{Research Sites}

The research was conducted at Faculty of Engineering Udayana University of Denpasar and Energy Laboratory of Electrical Engineering.

\subsection{Research Steps}

1. Data collection of non-linear load amounts.

2. Calculate the total capacity of active power (watt) non-linear load.

3. THD current analysis and THD voltage by doing simulation using ETAP software.

4. THDi maximum limit based on IEEE standard 519-2014.

5. Analysis of simulation results based on IEEE standard 519-2014.

3.3 Data Analysis

1. THD current analysis and THD voltage by doing simulation using ETAP software.

2. THDi maximum limit based on IEEE standard 519-2014.

\section{RESULTS AND DISCUSSION}

TABLE III

MEASUREMENTS OF THDI AND THDV ON 9 OHM GROUND RESISTIVITY VALUES

\begin{tabular}{|l|l|l|l|}
\hline No. & Measurements & $\begin{array}{l}\text { THD } \\
\text { Current } \\
\text { Value (\%) }\end{array}$ & $\begin{array}{l}\text { THD } \\
\text { Voltage } \\
\text { Value (\%) }\end{array}$ \\
\hline \multirow{2}{*}{1} & \multirow{2}{*}{, 4-9-2017 } & $\mathrm{R}=9,8$ & $\mathrm{R}=1,4$ \\
\cline { 3 - 4 } & & $\mathrm{S}=11,0$ & $\mathrm{~S}=1,2$ \\
\cline { 3 - 4 } & \multirow{2}{*}{$\begin{array}{l}\mathrm{T}, 5-9,5 \\
2\end{array}$} & $\mathrm{R}=9,9$ & $\mathrm{~T}=1,3$ \\
\cline { 3 - 4 } & \multirow{2}{*}{2017} & $\mathrm{~S}=11,0$ & $\mathrm{~S}=1,4$ \\
\cline { 3 - 4 } & \multirow{2}{*}{3} & $\mathrm{~T}=7,5$ & $\mathrm{~T}=1,3$ \\
\hline \multirow{3}{*}{3} & 2017 & $\mathrm{R}=9,8$ & $\mathrm{R}=1,4$ \\
\cline { 3 - 4 } & & $\mathrm{S}=11,0$ & $\mathrm{~S}=1,2$ \\
\cline { 3 - 4 } & & $\mathrm{T}=7,5$ & $\mathrm{~T}=1,3$ \\
\hline
\end{tabular}

4.1 Analysis of Harmonic Standard Determination THDi (Current) and THDv (Voltage)

TABLE IV

DATA ON CURRENT MEASUREMENT RESULTS AND VOLTAGE AT MAXIMUM EXPENSE

\begin{tabular}{|l|l|l|l|l|l|l|}
\hline $\begin{array}{l}\mathrm{N} \\
\mathrm{o}\end{array}$ & $\begin{array}{l}\mathrm{Fa} \\
\text { sa }\end{array}$ & $\begin{array}{l}\mathrm{I} \\
\text { am } \\
\text { per } \\
\mathrm{e}\end{array}$ & $\begin{array}{l}\mathrm{V} \\
\text { volt }\end{array}$ & $\begin{array}{l}\text { Cos } \\
\varphi\end{array}$ & $\begin{array}{l}\mathrm{P} \\
\text { (watt) }\end{array}$ & $\begin{array}{l}\mathrm{S} \\
(\mathrm{VA})\end{array}$ \\
\hline 1 & $\mathrm{R}$ & 64. & 221. & 0.8 & 1212 & 1426 \\
\hline
\end{tabular}

\begin{tabular}{|l|l|l|l|l|l|l|}
\hline & & 5 & 1 & 5 & 1.8 & 0.95 \\
\hline & $\mathrm{S}$ & 75. & 227. & 0.8 & 1452 & 1709 \\
& & 1 & 6 & 5 & 8.85 & 2.76 \\
\hline & $\mathrm{T}$ & 108 & 218. & 0.8 & 2011 & 2366 \\
& & .1 & 9 & 5 & 3.63 & 3.09 \\
\hline 2 & $\mathrm{R}$ & 2.9 & 222. & 0.8 & 549.4 & 646.4 \\
& & 9 & 5 & 5 & 1 \\
\hline & $\mathrm{S}$ & 3.0 & 225. & 0.8 & 576 & 677.7 \\
& & & 9 & 5 & & \\
\hline & $\mathrm{T}$ & 3.3 & 219. & 0.8 & 615.4 & 724.0 \\
& & 4 & 5 & & 2 \\
\hline
\end{tabular}

Data Trafo :

Transformator Capacity $(\mathrm{kVA})=160 \mathrm{kVA}$ Secondary Voltage $(\mathrm{kV}) \quad=380 \mathrm{~V}=0,38 \mathrm{kV}$ Impedansi $(\%) \quad=4 \%$

Analysis $\mathrm{SC}_{\mathrm{RATIO}}$ :

$\mathrm{SC}_{\text {ratio }}=\frac{I_{S C}}{I_{L}}$

$\mathrm{Isc}=\frac{\mathrm{KVA} \times 100}{\sqrt{3} \times \mathrm{KV} \times \mathrm{Z}(\%)}$

$\mathrm{KVA}$ trafo $=160, \mathrm{KV}$ trafo $=0.38$

Impedansi $Z=4 \%=0.04$, then:

$\mathrm{Isc}=\frac{160 \times 100}{\sqrt{3} \times 0.4 \times 0.04}$

$=\frac{16000}{\sqrt{3} \times 0.016}$

$=608457.56 \mathrm{~A}$

$\mathrm{I}_{\mathrm{L}}=\frac{K W}{P F \sqrt{3} \cdot K V}=\frac{20.113}{0.85 \times \sqrt{3 \times 0.4}}$

$=35993.844 \mathrm{~A}$

After the $\mathrm{I}_{\mathrm{sc}}$ and IL values are obtained, the current THD standard can be determined:

Sc ratio $=$ Isc $/ \mathrm{IL}=16.90449$, as in table 5 below, Sc value $<20$, then the standard THDi (current) is maximum $5 \%$ as table 1 .

The result of the measurement of $9 \mathrm{ohm}$ earthing system, the peak load THD current $>5 \%$, according to the results of analysis and IEEE 519 - 2014 standards should be $<5 \%$, so the quality of power system power is still low, it is one of the causes of the frequent parent panel (MDP) is damaged.

The treatment was performed by paralleling the grounding system of $\leq 3 \mathrm{ohms}$ resistance to MDP, measured at peak load, as shown in Table 5. 
TABLE V

RESULTS MEASUREMENTS THDI AND THDV GROUNDING SYSTEM R $\leq 3$ OHM

\begin{tabular}{|l|l|l|l|}
\hline No & Measurements & $\begin{array}{l}\text { THD } \\
\text { Current } \\
\text { Value } \\
(\%)\end{array}$ & $\begin{array}{l}\text { THD } \\
\text { Voltage } \\
\text { Value (\%) }\end{array}$ \\
\hline \multirow{2}{*}{1} & \multirow{2}{*}{$\mathrm{I}, 11-9-2017$} & $\mathrm{R}=4,2$ & $\mathrm{R}=1,4$ \\
\cline { 3 - 4 } & & $\mathrm{S}=5,0$ & $\mathrm{~S}=1,2$ \\
\cline { 3 - 4 } & & $\mathrm{T}=4,3$ & $\mathrm{~T}=1,3$ \\
\hline 2 & & $\mathrm{R}=4,2$ & $\mathrm{R}=1,4$ \\
\hline & & $\mathrm{S}=5,0$ & $\mathrm{~S}=1,2$ \\
\hline & & $\mathrm{T}=4,3$ & $\mathrm{~T}=1,3$ \\
\hline 3 & \multirow{2}{*}{$\mathrm{II}, 12-9-2017$} & $\mathrm{R}=4,2$ & $\mathrm{R}=1,4$ \\
\cline { 3 - 4 } & & $\mathrm{S}=5,0$ & $\mathrm{~S}=1,2$ \\
\cline { 3 - 4 } & & $\mathrm{T}=4,3$ & $\mathrm{~T}=1,3$ \\
\hline
\end{tabular}

\subsection{Discussion}

With grounding system $\leq 3 \mathrm{ohm}$ only effect on THD current with decrease of THD value respectively become: phase $R=4.2 \%$, phase $S=$ $5 \%$, phase $\mathrm{T}=4.3 \%$, means grounding system $\leq 3$ ohms THD current decreased according to IEEE $519-2014<5 \%$ standards. whereas THD voltage has no effect (THDv value is fixed). Several studies have suggested that THD repair can be done by filter installation. However, in this study the installation of $\leq 3 \mathrm{ohm}$ grounding system can reduce the value of THD.

\section{CONCLUSION}

Based on the results of the analysis concluded, among others:

1 . The result of sc value analysis $<20$, then the standard of THDi (current) according to IEEE 519 - 2014 standard) is maximum 5\%.

2 . The grounding system with a resistance value of $\leq 3 \mathrm{ohm}$ contributes to lowering the current THD value fairly well and delivering the value according to IEEE 519 - 2014 standard is < $5 \%$ for current THD and THD voltage $<5 \%$.

3. Based on the measurement of the parent panel with the grounding system $\leq 3 \mathrm{ohm}$ only affects the THD current with the decrease of THD value of each to: phase $\mathrm{R}=4.2 \%$, phase $\mathrm{S}=5 \%$ and phase $\mathrm{T}=4.3 \%$ means by grounding system $\leq 3 \mathrm{ohm}$ THD current becomes smaller than IEEE 519 - 2014 standard that is $<5 \%$. whereas THD voltage has no effect (has a fixed voltage THD value). In some studies mentioned THD repair can be done with the installation of filters.
However, in this study, installation of grounding systems that meet the standards can reduce the value of THD.

\section{REFERENCE}

[1] Wahyu Adi Merta, IW., dkk. 2016. Analisis Pemasangan Filter Pasif Untuk Menanggulangi Distorsi Harmonisa Terhadap Beban Non Linier di PT. Wisesa Group. E Journal Spektrum.

[2] Janardana, IGN. 2016. Sistem Pembumian Tipe Rod Sebagai Pengaman Peralatan Ruang Studio Teknik Arsitektur Gedung B Fakultas Teknik Universitas Udayana Jalan PB. Sudirman Denpasar. Denpasar : PS Teknik Elektro Unud - Perpustakaan Universitas Udayana.

[3] Janardana, IGN., dkk. 2016. Analisis Sistem Pembumian Sebagai Pengaman Peralatan Gedung Fakultas Teknik Universitas Udayana Denpasar. Laporan Penelitian : Fakultas Teknik Universitas Udayana.

[4] Hutaruk.TS.1987, Pengetanahan Netral dengan sistem Tenaga dan Pengetanahan Peralatan. Jakarta : Erlangga.

[5] Mahendra, IGMO. 2004. Study Kasus Kegagalan Proteksi Dari Bahaya Petir DI Hotel Sanur Beach Bali. Tugas Akhir. Denpasar : Teknik Elektro.

[6] Sutikno, dkk. 1997. External \& Internal Grounding. Bandung :DIVLAT PT. Telkom.

[7] Dugan, RC., dkk. 2012. Electrical Power Systems Quality, Third Edition. McGraw Hill Professional.

[8] Susiono. 1999. Penentuan Lokasi Lokasi Filter Harmonik Optimum Pada Sistem Distribusi Daya Listrik.Surabaya : Program Studi Teknik Elektro Institut Teknologi Sepuluh Nopember.

[9] Sunanda. 2012. Aplikasi Filter Pasif Sebagai Pereduksi Harmonik Pada Inverter Tiga Fase.

[10] IEEE Std 519TM-2014 Revision of IEEE Std 519-1992

[11] Suryajaya, A. 2011. Pengaruh Total Harmonic Distortion (THD) Pada Suatu Sistem.Semarang : Program Studi Teknik Elektro Jurusan Teknologi Industri Universitas Katolik Soegijapranata. 